\title{
Improved Understanding of English Literacy with Small Group Discussion Model Assisted by Digital Comics
}

\author{
Peningkatan Pemahaman Literasi Bahasa Inggris dengan Model Small Group Discussion \\ Berbantuan Komik Digital
}

\author{
Bhuana Dewati \\ SMP N 1 Wanadadi \\ bhuanadewati@gmail.com
}

\begin{abstract}
Literacy skills in reading English need to be mastered by junior high school students. However, the reality in Junior High School $N 1$ Wanadadi obtained many students who still can not read English. This indicates that his literacy ability is still low. Therefore, an innovation in English learning is needed by supporting technological developments. One of them is by learning Small Group Discussion assisted by digital comics. This study is a Class Action Research with two silus, and each cycle consists of three meetings. Classroom action research procedures in the form of planning, implementation, observation, and reflection. The data analysis technique used is descriptive analysis. The research subjects of students of class VIIID of SMP Negeri 1 Wanadadi semester 1 amounted to 30 students. The data collection techniques are observations, interviews, and tests. The results showed that the use of a Small Group Discussion model assisted by digital comics can improve English literacy skills. Students look actively studying in the classroom and can learn independently.
\end{abstract}

Keywords: small group discussion, digital comic, english literacy.

Abstrak

Kemampuan literasi dalam membaca Bahasa Inggris perlu dikuasai oleh siswa SMP. Namun, kenyataan di SMP N 1 Wanadadi diperoleh banyak siswa yang masih belum bisa membaca Bahasa Inggris. Hal ini menandakan kemampuan literasinya masih rendah. Oleh karena itu diperlukan suatu inovasi pembelajaran Bahasa Inggris dengan mendukung perkembangan teknologi. Salah satunya dengan pembelajaran Small Group Discussion berbantuan komik digital. Penelitian ini merupakan Penelitian Tindakan Kelas dengan dua siklus, dan setiap siklus terdiri dari tiga pertemuan. Prosedur penelitian tindakan kelas berupa perencanaan, pelaksanaan, observasi, dan refleksi. Teknik analisis data yang digunakan adalah analisis deskriptif. Subjek penelitian siswa kelas VIIID SMP Negeri 1 Wanadadi semester 1 sejumlah 30 siswa. Teknik pengumpulan datanya observasi, wawancara, dan tes. Hasil penelitian menunjukkan bahwa penggunaan model Small Group Discussion berbantuan komik digital dapat meningkatkan kemampuan literasi Bahasa Inggris. Siswa terlihat aktif belajar di kelas dan dapat belajar secara mandiri.

Kata kunci: small group discussion, komik digital, literasi bahasa inggris

(*) Corresponding Author: bhuanadewati@gmail.com, 0812-1592-216

\section{PENDAHULUAN}

Bahasa Inggris merupakan salah satu Bahasa internasional yang wajib dipelajari siswa dari SD-SMA. Kemampuan berbahasa Inggris harus bisa diperdalam siswa dengan memperdalam kosa kata Bahasa Inggris. Pembelajaran Bahasa Inggris membuat Sebagian siswa SMP N 1 Wanadadi. Pemahaman membaca adalah salah satu jenis keterampilan bahasa dasar. Pemahaman membaca adalah keterampilan hidup yang perlu dipelajari oleh siswa. Ini berkaitan dengan teks yang berisi informasi sehingga siswa dapat memahaminya dengan baik. Para siswa harus dapat membaca dengan efisien. Ini adalah dengan memahami kosa kata, tata bahasa dan ide-ide atau informasi dengan teks. Dengan memahami aspek-aspek tersebut dalam pemahaman membaca, siswa dapat memahami informasi dalam teks. Pemahaman membaca memiliki peran penting dalam pembelajaran Bahasa Inggris, dan pengembangan keterampilan ini terutama ditekankan dalam Kurikulum 2013, karena dengan menguasai keterampilan membaca, siswa 


\section{Improved Understanding of English Literacy with Small Group \\ Discussion Model Assisted by Digital Comics \\ Bhuana Dewati \\ SMP N 1 Wanadadi}

akan dapat memperoleh lebih banyak informasi untuk memajukan mereka dalam pengetahuan, teknologi, seni dan budaya.

Pembelajaran Bahasa Inggris yang biasa di SMP N 1 Wanadadi selama pandemi ini lebih banyak menggunakan WA grup dan google classroom. hal ini menjadikan guru kurang mengontrol kemampuan masing-masing siswa dalam memahami pembelajaran Bahasa Inggris. Seseringkali guru memberikan materi dalam bentuk video dan powerpoint untuk dipahami oleh siswa, Namun, pada saat siswa di tes untuk memahami bacaan dari dongeng ataupun novel mereka banyak yang bingung untuk mengartikan isi ceritanya. Oleh karena itu dibutuhkan model dan strategi yang cocok agar siswa bisa memahami isi cerita dan meningkatkan literasi Bahasa Inggris siswa. Salah satu model yang cocok adalah Small group discussion.

Small Group Discussion (SGD) merupakan diskusi yang dilakukan dengan menginstruksikan siswa untuk melakukan kegiatan tertentu, seperti menemukan makna sesuatu, mencari alasan tentang suatu peristiwa tertentu, atau memecahkan masalah secara berpasangan atau kelompok (Huda, 2013). Pembelajaran melalui SGD menjadikan siswa sebagai center of the learning process, sehingga pembelajaran menjadi berpusat pada siswa (Boruvkova \& Emanovsky, 2016).

Pada perkembangan zaman yang serba digital saat ini, pengaruh teknologi sudah berkembang pesat di bidang Pendidikan. Pembelajaran online yang sekarang dilakukan di sekolah-sekolah menuntut siswa dan guru untuk beradaptasi dengan teknologi. Banyak media pembelajaran yang sudah menerapkan bantuan teknologi, sehingga mempermudah guru dalam mengajar di kelas. Salah satu media pembelajaran yang cocok untuk meningkatkan literasi Bahasa Inggris siswa yaitu dengan menggunakan komik. Komik merupakan cerita bergambar yang menampilkan cerita dalam suatu peristiwa (Riwanto \& Wulandari, 2019). Komik saat ini tersedia tidak hanya dalam bentuk cetak saja, tetapi tersedia pula dalam bentuk digital. Komik digital menampilkan gambar yang sesuai dengan realita dalam Bahasa Inggris dan dapat diakses menggunakan smartphone. Komik digital sangat praktis digunakan oleh siswa, dan sangat fleksibel sehingga siswa dapat belajar tanpa Batasan ruang dan waktu (Kanti dkk, 2018). Listianingsih dkk. (2021) menyatakan bahwa dengan pembelajaran berbantuan komik digital menjadikan siswa gemar membaca dan dapat meningkatkan literasi siswa.

\section{METODE}

Penelitian ini merupakan Penelitian Tindakan Kelas (PTK) yang terdiri atas 2 siklus, dan masing-masing siklus terdiri dari 3 pertemuan. Subjek penelitian ini adalah siswa kelas VIIID SMP N 1 Wanadadi sejumlah 36 siswa. Sumber data dalam penelitian tindakan kelas ini meliputi siswa, teman sejawat, dan dokumen. Prosedur penelitian tindakan kelas berupa perencanaan, pelaksanaan, observasi, dan refleksi.

Pada tahap perencanaan, peneliti mengkaji silabus untuk mengetahui kompetensi dasar dan materi yang akan diajarkan. Kemudian peneliti menyusun RPP, menyiapkan media, dan menyusun instrumen penelitian. Pada tahap pelaksanaan peneliti melakukan action di kelas dengan menerapkan model Small Group Discussion dengan bantuan media pembelajaran komik digital. Tahap observasi peneliti mengamati kegiatan siswa selama pembelajaran. Tahap akhir yaitu refleksi, peneliti melakukan evaluasi terhadap jalannya pembelajaran.

Teknik pengumpulan data yang digunakan adalah teknik triangulasi dengan tes, observasi, wawancara, dan angket. Instrumen yang digunakan dalam penelitian ini merupakan lembar evaluasi literasi Bahasa Inggris. Analisis data yang dilakukan dalam penelitian ini adalah teknik analisis deskriptif yang meliputi data kuantitatif dan data kualitatif sebagai dasar untuk mengetahui keefektifan dan keberhasilan tindakan serta pedoman analisis data perlu adanya 
indikator kinerja dalam penelitian yaitu $80 \%$ siswa tuntas mencapai KKM yang diukur dari hasil tes evaluasi siswa yang mendapat nilai $\geq 65$. Nilai 65 sebagai kriteria ketuntasan minimal.

\section{HASIL DAN PEMBAHASAN}

\section{Hasil}

\section{Kondisi Awal}

Berdasarkan hasil kemampuan literasi memahami Bahasa Inggris siswa pada tes awal (pre-test) yang diberikan sebelum pelaksanaan tindakan, diperoleh data bahwa nilai tertinggi yang diperoleh oleh siswa di kelas VIIID adalah 74 dan skor terendah adalah 42 dengan ratarata kelas adalah 58. Siswa kelas VIIID masih belum memahami bacaan Bahasa Inggris dengan baik. Hal ini perlu dilakukan penelitian lebih lanjut dan inovasi dalam proses pembelajaran bahasa Inggris yaitu dengan menggunakan model Small Group Discussion dengan bantuan media pembelajaran komik digital.

\section{Siklus I}

Pada siklus I terdiri dari 4 tahap, yaitu perencanaan, tindakan, pengamatan, dan refleksi. Pada tahap perencanaan guru membuat instrumen pembelajaran, RPP, dan silabus. Pada tahap tindakan guru melaksanakan proses pembelajaran bahasa Inggris dengan model Small Group Discussion dengan bantuan media pembelajaran komik digital. Siswa dibagi dalam beberapa kelompok kecil. Setelah itu di dalam kelompok kecil siswa bekerja sama untuk menelaah bacaan dari komik digital. Setiap siswa mempunyai pasangan masing-masing dalam kelompok kecil tersebut untuk memahami bacaan Bahasa Inggris, menelaah dan menyampaikan hasil diskusinya. Teman yang lain menanggapi hasil diskusinya.

Setelah diberi perlakuan selama 3 kali pertemuan, semua siswa tersebut diberi tes untuk melihat sejauh mana pemahaman literasi Bahasa Inggris. Adapun perolehan nilai siswa pada siklus I ini yaitu skor terendah 62, skor tertinggi 76, dan skor rata-rata 64, yang terlihat pada tabel 1.

\begin{tabular}{lc}
\multicolumn{1}{c}{ Tabel 1. Literasi Bahasa Inggris Siswa pada Siklus I } \\
\hline \multicolumn{1}{c}{ Aspek } & Nilai \\
\hline Nilai minimal & 62 \\
Nilai maksimal & 76 \\
Nilai rata-rata & 64 \\
Persentase ketuntasan siswa & $57 \%$ \\
\hline
\end{tabular}

Dari hasil skor tersebut terlihat bahwa hasil yang diperoleh siswa setelah pemberian tindakan pada siklus I, menunjukkan bahwa tingkat literasi bahasa Inggris mereka mengalami peningkatan. Meskipun mengalami peningkatan namun masih berada dalam kategori rendah karena skor rata-rata siswa masih di bawah KKM. Oleh karena itu perlu dilakukan lagi tindakan pada siklus II.

\section{Siklus II}

Berdasarkan hasil evaluasi dan refleksi yang dilakukan pada siklus I, maka pada siklus II, siswa masih sama diberi perlakuan seperti pada siklus I yaitu dengan model Small Group Discussion dengan bantuan media pembelajaran komik digital. Dalam pembelajaran tersebut setiap siswa diberi kesempatan untuk berdiskusi dengan kelompok kecil yang sudah dibagi oleh guru. Guru memberikan materi dengan menggunakan komik digital yang dapat diakses siswa dengan menggunakan smartphone.

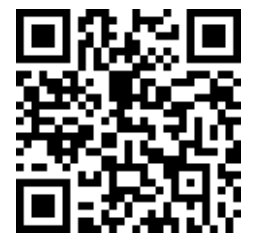

DOI PUBLIKASI https://doi.org/10.37010/int.v2i2 


\section{Improved Understanding of English Literacy with Small Group \\ Discussion Model Assisted by Digital Comics \\ Bhuana Dewati \\ SMP N 1 Wanadadi}

Dalam pembelajaran dengan menggunakan media komik digital terlihat siswa sangat antusias belajar Bahasa Inggris. Komunikasi antara siswa dan guru terarah, dalam artian terjadi interaksi dua arah dalam pembelajaran, sehingga pembelajaran Bahasa Inggris yang berlangsung interaktif. Setelah dilakukan dalam 3 pertemuan, maka di akhir pertemuan dilakukan postest atau evaluasi untuk memahami literasi Bahasa Inggris siswa. Adapun perolehan vocabolary siswa pada siklus II ini yaitu skor terendah 68 , skor tertinggi 84 , dan skor rata-rata 73 , seperti terlihat pada tabel 2 .

\begin{tabular}{lc} 
Tabel 2. Literasi Bahasa Inggris Siswa pada Siklus II \\
\hline \multicolumn{1}{c}{ Aspek } & Nilai \\
\hline Nilai minimal & 68 \\
Nilai maksimal & 84 \\
Nilai rata-rata & 73 \\
Persentase ketuntasan siswa & $82 \%$ \\
\hline
\end{tabular}

Berdasarkan implementasi tindakan pada siklus II ini dapat diperoleh data tentang hasil pembelajaran yaitu 1) guru memiliki waktu untuk memonitoring siswanya dalam pembelajaran, 2) siswa sangat antusias belajar Bahasa Inggris dengan menggunakan komik digital, 3) pembelajaran dengan model Small Group Discussion dapat mengaktifkan siswa untuk berdiskusi dan aktif di kelas.

\section{Pembahasan}

Pada pembelajaran Bahasa Inggris dengan menggunakan model Small Group Discussion dengan bantuan media pembelajaran komik digital terjadi peningkatan yang cukup signifikan dari kondisi awal sampai dengan siklus ke II. Berawal dari kondisi siswa yang tidak menyukai Bahasa Inggris dengan nilai literasi Bahasa Inggris siswa sangat rendah yaitu memiliki rata-rata 58, kemudian siswa diberi perlakuan pembelajaran bahasa Inggris model Small Group Discussion dengan bantuan media pembelajaran komik digital. Peningkatan ketuntasan belajar siswa dari kondisi awal ke siklus I mencapai peningkatan sebesar $12 \%$. Kemudian di siklus ke II diberi perlakukan yang sama dan terjadi peningkatan dari siklus I sebesar 25\%. Hal ini menunjukkan bahwa pembelajaran Small Group Discussion mampu meningkatkan kemampuan literasi Bahasa Inggris siswa. Hal ini senada dengan penelitian Utami dkk (2019) yang menyatakan bahwa dengan menggunakan pembelajaran Small Group Discussion mampu meningkatkan pemahaman konsep siswa dan menjadikan siswa aktif dalam belajar. Simorangkir dkk. (2019) juga menyatakan dengan pembelajaran Small Group Discussion prestasi siswa dalam memahami pemahaman membaca menjadi lebih baik daripada sebelumnya.

Media pembelajaran sangat mempengaruhi proses pembelajaran siswa di kelas. Dengan menggunakan media pembelajaran yang sesuai dengan kondisi zaman saat ini menjadikan media pembelajaran berbasis teknologi mudah dipahami dan digunakan oleh siswa. Pembelajaran komik digital yang mendukung model pembelajaran Small Group Discussion mampu meningkatkan pemahaman literasi Bahasa Inggris siswa. Sejalan dengan Zupita dkk. (2020), diperoleh informasi bahwa dalam pendidikan literasi bahasa Inggris, mahasiswa rata-rata memiliki level tinggi dan lebih banyak menggunakan teknologi digital, sehingga TI sangat melekat dalam proses pendidikan literasi mahasiswa era ini, dan merupakan sarana tepat untuk mengembangkan literasi mahasiswa kini. Dengan begitu perkembangan teknologi saat ini sangat mendukung tingkat belajar siswa. Suri dkk. (2021) menyatakan bahwa komik digital sangat interaktif dan cocok untuk pembelajaran di tingkat SMP. Media pembelajaran berbantuan teknologi tersebut telah memenuhi standar keefektifan untuk pembelajaran, dibuktikan dengan hasil pretes dan postes meningkat dalam memahami pemahaman bacaan Bahasa Inggris 
(Supriyono \& Sugirin, 2014). Penggunaan komik digital sesuai dengan tingkat perkembangan zaman saat ini yang serba digital. Wahyudin dkk. (2020) menyatakan bahwa penggunaan komik digital dengan menggunakan Tondoo selain dapat meningkatkan kemampuan membaca siswa juga dapat meningkatkan kemampuan menulis Bahasa Inggris siswa.

\section{PENUTUP}

Berdasarkan hasil penelitian dan pembahasan, maka dapat disimpulkan bahwa pembelajaran bahasa Inggris dengan menggunakan Small Group Discussion dengan bantuan media pembelajaran komik digital mampu meningkatkan literasi Bahasa Inggris siswa kelas VIIID SMP N 1 Wanadadi. Hal ini terlihat dari nilai rata-rata kemampuan literasi Bahasa Inggris setiap siklusnya selalu meningkat. Peningkatan ketuntasan kemampuan literasi Bahasa Inggris siswa juga meningkat setiap siklusnya yaitu dari siklus prasiklus ke siklus I sebesar $12 \%$, dan dari siklus I ke siklus II sebesar 25\%. Pembelajaran dengan menggunakan Small Group Discussion dengan bantuan media pembelajaran komik digital membuat siswa semakin aktif dalam belajar bahsa inggris. Selain itu, siswa juga semakin percaya diri dalam membaca bacaan Bahasa inggris.

\section{DAFTAR PUSTAKA}

Borůvková, R., \& Emanovský, P. (2016). Small group learning methods and their effect on learners' relationships. Problems of Education in the 21st Century, 70, 45.

Huda, M. (2013). Cooperative Learning. Yogyakarta: Pustaka Pelajar.

Kanti, F. Y., Suyadi, B., \& Hartanto, W. (2018). Pengembangan media pembelajaran komik digital pada kompetensi dasar sistem pembayaran dan alat pembayaran untuk siswa kelas $\mathrm{X}$ IPS di MAN 1 Jember. JURNAL PENDIDIKAN EKONOMI: Jurnal Ilmiah Ilmu Pendidikan, Ilmu Ekonomi Dan Ilmu Sosial, 12(1), 135-141.

Listianingsih, M., Astuti, I. A. D., Dasmo, D., \& Bhakti, Y. B. (2021). Android-Based Comics: An Alternative Media to Improve Scientific Literacy. Jurnal Penelitian dan Pembelajaran IPA, 7(1), 105-117.

Riwanto, M. A., \& Wulandari, M. P. (2019). Efektivitas Penggunaan Media Komik Digital (Cartoon Story Maker) dalam pembelajaran Tema Selalu Berhemat Energ. JURNAL PANCAR (Pendidik Anak Cerdas dan Pintar), 2(1).

Simorangkir, N., Nurmanik, T., \& Yuliwati, Y. (2019). Meningkatkan Pemahaman Bacaan Siswa melalui Small Group Discussion. In Prosiding Seminar Nasional Pendidikan STKIP Kusuma Negara.

Supriyono, K., \& Sugirin, S. (2014). Pengembangan media pembelajaran membaca bahasa inggris smp berbasis web. Jurnal Inovasi Teknologi Pendidikan, 1(1), 49-64.

Suri, D. A., Astuti, I. A. D., Bhakti, Y. B., \& Sumarni, R. A. (2021). E-Comics as an Interactive Learning Media on Static Fluid Concepts. In 2nd Annual Conference on Social Science and Humanities (ANCOSH 2020) (pp. 358-61). Atlantis Press.

Utami, P., Ismaniati, C., \& Mustadi, A. (2019). Peningkatan Pemahaman Konsep Mahasiswa Pendidikan Guru Sekolah Dasar Melalui Small Group Discussion. Didaktika Tauhidi: Jurnal Pendidikan Guru Sekolah Dasar, 6(1), 1-14.

Wahyudin, A. Y., Jepri, D., Simamora, M. W., Pratiwi, I. W., \& Rina, A. (2020). Penggunaan komik digital Toondoo dalam pembelajaran Bahasa Inggris tingkat sekolah menengah. Journal of Social Sciences and Technology for Community Service (JSSTCS), 1(1), 1-6. 


\section{Improved Understanding of English Literacy with Small Group \\ Discussion Model Assisted by Digital Comics \\ Bhuana Dewati}

SMP N 1 Wanadadi

Zupita, N., Fitriani, Y. E., \& Rohayati, Y. (2020). Ti Dalam Pendidikan: Studi Literasi Bahasa Inggris Dalam Membaca Dan Menulis Dikalangan Mahasiswa Era Digital. In Prosiding Seminar Nasional Pendidikan (Vol. 2, pp. 236-244). 